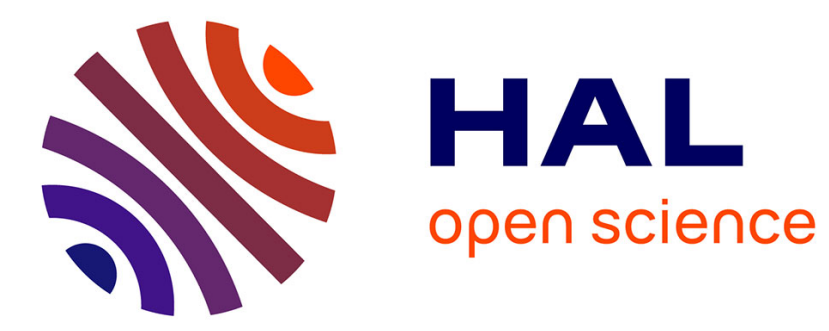

\title{
Elie Halévy's first lectures on the history of European socialism
}

Ludovic Frobert

\section{To cite this version:}

Ludovic Frobert. Elie Halévy's first lectures on the history of European socialism. Journal of the History of Ideas, 2007, 68 (2), pp.329 - 353. 10.1353/jhi.2007.0014 . halshs-00213503

\section{HAL Id: halshs-00213503 https://shs.hal.science/halshs-00213503}

Submitted on 19 Jun 2017

HAL is a multi-disciplinary open access archive for the deposit and dissemination of scientific research documents, whether they are published or not. The documents may come from teaching and research institutions in France or abroad, or from public or private research centers.
L'archive ouverte pluridisciplinaire HAL, est destinée au dépôt et à la diffusion de documents scientifiques de niveau recherche, publiés ou non, émanant des établissements d'enseignement et de recherche français ou étrangers, des laboratoires publics ou privés. 
FROBERT, Ludovic (2007). Journal of the history of ideas. Vol. $68 \mathbf{N}^{\circ} 2$. « Elie Halévy's first lectures on the history of European socialism ». P. 329-353.

The definitive version is available at

http://muse.jhu.edu/login?uri=/journals/journal of the history of ideas/v068/68.2frobert.html

Elie Halévy's First Lectures on the

History of European Socialism

\author{
Ludovic Frobert \\ Chargé de Recherches \\ Centre National de la Recherche Scientifique \\ Ecole Normale Supérieure Lettres et Sciences Humaines
}

Adresse :

ENS-LSH

15 Parvis Descartes

69363 Lyon cedex 07

France

Ludovic.Frobert@ens-lsh.fr 
Elie Halévy (1870-1937) is not only hailed for his contributions to the history of utilitarianism or to the history of modern democracy in England, but he is also generally depicted as a great liberal thinker. French commentators, from Raymond Aron to now Nicolas Baverez, have noted the Montesquieu-Tocqueville-Halévy intellectual tradition ${ }^{\mathrm{i}}$ Indeed, Halévy's perception of socialism's contradictory nature is considered one of his major intellectual contributions. In his lecture on "The Era of Tyrannies", he claimed that since socialism's ambition was to articulate two major contradictory tenets - namely emancipation and organisation - its outcome could only be chaos and tyranny ${ }^{\text {ii }}$. Published in 1936, Halévy's paper influenced a whole generation of French liberal thinkers, notably those concerned with economics, such as Raymond Aron, Robert Marjolin, Etienne Mantoux. Translated into English by May Wallas and published in Economica, it also had some influence on Friedrich Hayek in his writing of The Road to Serfdom ${ }^{i i i}$.

The liberalism of Halévy's work is unquestionable and is relevant to his later texts, notably those of his most pessimistic years, the Thirties. Before the Great War, however, Halévy's analysis of socialism was more positive. It is telling that he wrote in 1906: "Universalized liberty is democracy; and universalized democracy, when it is extended from the political field to the economic one, is nothing but: socialism"iv ${ }^{\text {, What }}$ interest the young Halévy, then a self-proclaimed dreyfusard and republican intellectual, is the potential for social and political control inherent in economic practices. This interest can be found in all of his major texts of the 1896-1914 period ${ }^{\mathrm{V}}$. 
It will come as no surprise therefore, that Halévy's lectures on European Socialism, delivered at the Ecole Libre des Sciences Politiques between 1902 and 1937, bear the traces of such an evolution. Some of these lectures were published in 1948, i.e. ten years after Halévy's death, by some of his followers, who underscored Halévy's hostility to socialism. Within the Halévy Archives ${ }^{1}$ still lie, however, unknown and unpublished, the near totality of the first series of lectures on socialism delivered in 1902. It is the purpose of this paper to shed new light on Halévy by exposing the content of this particular series of lectures, as yet unstudied. A close reading of this set shows a very different pre-1914 Halévy, one insisting notably on Marx's seminal role in understanding capitalism and on the progress of an economic system in which the influence of tradeunions, cooperatives and, above all, the State would be decisive. In short, this early Halévy, more republican ${ }^{\mathrm{vi}}$ than liberal, suggests that a positive dialogue $^{\text {vii }}$ between the two tenets of socialism - emancipation and organization - could and should be undertaken in modern industrial societies and that this dialogue is the prerequisite of social and political progress.

The 1902 lectures, newly presented here, are thus of capital interest for a reinterpretation of the thought of one of the most influencal French intellectual of the early $20^{\text {th }}$ century. A first section offers new insights into the republican intellectual background of Halévy's early work and historical details about his later shift away from socialism. In section 2 to 5 , an attempt is made to present Halévy's toying with socialism through the content of his 1902 lectures. A final section summarizes the results of the series of lectures presented by the young Halévy in the first term of 1902 on a reinterpretation of Halévy's stand on socialism and liberalism.

\footnotetext{
${ }^{1}$ The Halévy Archives are held in the Library of the Ecole Normale Supérieure, Paris.
} 


\section{ELIE HALEVY AND SOCIALISM}

Philosopher, intellectual historian, and historian of economic and political practices, Elie Halévy (1870-1937) devoted all his energy to the study of two phenomena which, in nineteenth-century Europe, supported the affirmation and then the spread of civil and political, but also economic and social liberties.

Halévy was, to start, a scrupulous analyst of the changes in social conscience in England. At the very beginning of the century, he published the three-volume work $\mathrm{La}$ Formation du Radicalisme Philosophique (1901-1904) ${ }^{\mathrm{viii}}$, and in 1912 he began his monumental Histoire du Peuple Anglais au 19e Siècle (left unfinished) with a hypothesis, henceforth a classic one, ${ }^{\text {ix }}$ relating to the crucial importance of Methodist ferment in the development of liberal democracy in England. ${ }^{x}$

Halévy was, very early on, also drawn to the phenomenon of European socialism. Named professor at the Ecole Libre des Sciences Politiques (ELSP) in 1898 to teach the evolution of political ideas in England, he launched in the academic year 1901-1902 another course on the history of European socialism. He alternated between these two professional duties for about thirty five years. Halévy's works on socialism were published, in book form, after his death: thus did the collection entitled $L$ 'Ere des Tyrannies: Etudes sur le Socialisme et la Guerre ${ }^{x i}$ appear in 1939, and his work Histoire du Socialisme Européen, ${ }^{x i i}$ also published posthumously, in 1948. 
This latter work was published by the society of the Friends of Elie Halévy. Presided over by Célestin Bouglé, this organization's goal was to publish the University course on European socialism that Halévy had not had the time to write up himself. Several former students of Halévy collaborated on this edition: Jean-Marcel Jeanneney, Pierre Laroque, Etienne Mantoux, Robert Marjolin, but also a friend of the Halévy family, Raymond Aron (who would manage the project after the death of Bouglé in 1940). In the foreword, Aron brought up the difficulty of the task. First, Halévy lectured freely from his abundant notes. Second, from 1901 to 1937 the course had undergone changes, with the history of practices gradually supplanting the history of doctrines. Finally, the subject had never been addressed fully in any one year ${ }^{x i i i}$. Thus, the 1948 edition forsook the definitive outline that Halévy had found the time to draw up in the spring of 1937 and proposed an edited version of the course, based on notes taken by some students in attendance at the Ecole Libre des Sciences Politiques in the thirties and on some lectures written out longhand by Halévy dating from the turn of the century. Furthermore, the author had not had time to draw up a conclusion for the course. The editors believed, however, that Halévy, had earlier formulated a conclusion, in the paper entitled "The Era of Tyrannies", presented November 1936 at the Société Française de Philosophie: Socialism had paved the way for modern tyrannies insofar as the two ideas that form the basis of socialism, emancipation and organization, were irreconcilable. Several long citations from that lecture of 1936 were thus reproduced in the work of 1948 as the conclusion. ${ }^{\text {xiv }}$

The very year Histoire du Socialisme Européen au 19e Siècle appeared, Jean-Paul Sartre voiced his rejection of its conclusion, or more precisely of what, he felt, had been 
falsely concluded from Halévy: "[...] to dare to say that socialism suffers from this contradiction, one would have to be unaware that ideologies have a dialectical becoming; an evolving collective whole suffers from its contradictions only in the eyes of those who believe that the contradictions are frozen and unchangeable" ${ }^{\prime x v}$. The philosopher concluded that passage through contradictions is inherent to socialism and it alone guarantees progress toward a genuine "concrete liberty". In connection with Sartre's intervention, it is timely to emphasize two things: first, the 1948 edition is an artificial construct; second, Halévy's opinion of socialism was without a doubt less radical than the pessimistic conclusion of 1936 would lead us to believe and furthermore may itself have experienced numerous evolutions.

"Elie's constant despair takes me aback," wrote the French philosopher Alain (Emile Chartier) to Florence Halévy in $1936^{\text {xvi }}$. "In this flood of hate, fury, and violence [of the First World War], I feel inundated, lost, stunned"xvii, Halévy was to confess to Xavier Léon in 1915. His analyses were marked by growing pessimism, which would later be judged excessive in regard to the development of socialism, as well as of liberal democracies. ${ }^{\text {xvii }}$ Numerous earlier texts reveal an author much more balanced and attentive to the ambiguous lessons of history.

If one can only speculate concerning the last phase of Halévy's thoughts on European Socialism, it cannot be said to be the same concerning his earlier stages. In fact, almost the whole of his first series of lectures given at the Ecole Libre des Sciences Politiques between January and April of 1902 can be found in the Halévy Archives. The eleven lectures are organized into four large groups: the first, on Friedrich List and German Historicism, the second, on Marxism, which can be considered the pivotal point 
of the course in 1901, the third, on an evaluation of Marxism in relation to the modern phenomenon of capital concentration, and finally, the fourth, on the transformations that European Socialism displayed in theory and in practice at the turn of the century.

Before the presentation of these lectures, however, we must briefly explain Halévy's early biography and the historical details of the context of his course.

Educated at the Ecole Normale Supérieure, Halévy was a philosopher by training. Recipient of the "aggregation" in 1892, he participated in the renewal of neo-Kantian rationalism and founded the Revue de Métaphysique et de Morale along with Xavier Léon and Léon Brunschvig. His first title to be on bookshelves was a reflection on the Platonic dialectic ${ }^{\mathrm{xix}}$. In 1896, however, he became interested in the work of Jeremy Bentham, and in the history of English Radicalism, which was to be the subject of his French dissertation. By the turn of the century, Halévy began slowly to distance himself from pure philosophy and to find growing interest in economic doctrines. This direction, unexpected of a young French philosopher, can be explained for the most part by two related elements: on the one hand, by the acuity of his republican political conscience ${ }^{\mathrm{xx}}$ and on the other hand, by the dissatisfaction he felt with what the main progressive intellectual trends of his time were contributing to reflection on 'concrete liberty', especially concerning its economic and social aspects. This observation is brashly laid out in his review of the book by John Hobson, The Social Problem" ${ }^{x x i}$ : "It is a profound understanding of political economy that allows Mr. Hobson to speak about social concerns in rigorous language, and to escape from both the formalism of Kantian doctrine 
on law and the sometimes abstract, sometimes metaphorical, formalism of contemporary sociology, and finally, instead of refuting or defending abstract theory on the rights of man, to revise, complete, or in some sense, fill it in."

Roughly between the years 1896 and 1906, Halévy explored the main strands of economic ideas. He studied the Classical economists and the utilitarians ${ }^{\text {xxii }}$, the socialist aspect of the Ricardien heritage ${ }^{\mathrm{xxiv}}$, the Marxism of Marx and his epigones, Marginalism especially in the Austrian version advocated by Carl Menger and Eugen Böhm-Bawerk, and the economic ideas of the Saint-Simonians ${ }^{\mathrm{xxv}}$. In 1906, he published a very long article, "The Principles of the Distribution of Wealth", in the Revue de Métaphysique et de Morale, a sort of manifesto in which he developed his own economic ideas. In the same year, in the signed entry for "political economy" in André Lalande's Vocabulaire Technique et Critique de la Philosophie, he significantly proposed the following: "[Political economy is a] Science having as its goal an understanding of the phenomena and (if the nature of these phenomena allow for it, which is under debate,) the determination of laws concerning the distribution of wealth as well as its production and consumption, in so far as these phenomena are linked to its distribution". xxvi During the academic year 1905-1906, he began to sense that a single work on economic and social doctrines would not do; instead, he branched off toward the study of concrete practices, in particular, of those in England. Thus, in 1906 his two articles on Methodism appeared, precursors to the first volume of his Histoire du Peuple Anglais au 19e, which would appear six years later ${ }^{\mathrm{xxvii}}$. 
The 1901-1902 course was taught during a crucial period in the history of Socialism, marked in Europe by the Revisionist critique and by the Parlementarian temptation. In France, the same period was also dominated by a vague desire for union between rival socialist groups; at the intellectual level, this was characterized by an important awakening heralded by, for example, the quick translations, after 1890, of Marx's main titles ${ }^{\text {xxviii }}$ or the rigor of the new analyses proposed by Jean Jaurès, Georges Sorel or Lucien Herr ${ }^{x x i x}$. Emile Boutmy, then director of the Ecole Libre des Sciences Politiques, proposed to Halévy, who was at first reluctant, to do a course on socialism, in the School's newly formed "economic and social" section, opened in 1900. The Ecole, founded in the aftermath of the Franco-Prussian War, aimed at presenting a positivist approach to education in contemporary political, economic, and social phenomena ${ }^{\mathrm{xxx}}$. At the turn of the century, in this traditionally liberal school where social economics was being taught by followers of Frédéric Le Play, ${ }^{x x i}$ a special interest was accorded to welfare socialism ("socialisme de la chaire"), which, in Germany, had allowed revolutionary socialism to be defused. Hence, it is in this perspective that Boutmy entrusted Halévy with the burden of a series of eleven lectures. In order to study this modern doctrinal phenomenon and in order to avoid nationalist undertones, it was entitled "The Evolution of Economic and Social Doctrine in England and Germany in the Second Half of the Nineteenth Century." In fact, instruction was to be guided by the analysis of the German model, and, significantly, Halévy asked for the help and guidance of Célestin Bouglé, François Simiand, and Lucien Herr. ${ }^{\text {xxxii }}$ The content of this first course was, it seems, the following: 1) Introduction; 2) Friedrich List and the national political economy; 3) The German Historical School; 4) Marxism and value theory; 5) 
Austrian value theory and interest theory; 6) the materialist conception of history; 7) the Marxist theory of the merging and concentration of capital; 8) Concentration in agriculture and industry; 9) Unionism; 10) Cooperation; and 11) State Socialism. ${ }^{\text {xxxii }}$

The way he began the course allowed Halévy to limit instruction to the study of German socialism; in nineteenth-century Germany, a triple reaction had formed against the individualism, rationalism, and non-interventionist policy of the English liberal political economy. Under the influence of Hegel and Fichte, nationalism rose up against cosmopolitan individualism, empiricism was set in apposition to deductive rationalism, and lastly, interventionism presented itself in its socialist form (arguments for it having been borrowed from the founders of economic liberalism in order to turn them back against them). According to Halevy, a solid study, centered on the immense "socialist and interventionist reaction", xxxiv was possible in so far as Marxist doctrine, basically synthetic, would, at one point, "crystallize" the socialist movement. It would, however, be necessary, to measure the fecundity of Marxism, to expurgate it of its "apocalyptic and utopian elements", ${ }^{\mathrm{xxv}}$ which could be explained as circumstantial. For Halevy, Marxism offered, leaving some exaggerations aside, a realistic picture of all the major upheavals of the modern economic system, and it even allowed for emphasis on "certain characteristics of the political economy of Europe in the century that is beginning". xxxvi Over and above its doctrinal side, Marxism also allowed for the prediction of the time when socialism "will have to submit to governmental opportunism". ${ }^{x x x v i i}$ In this new type of capitalism, however, would economic regulation be principally unintentional and brought on by the spontaneous blooming of cooperatives, or would it rather be intentional, making an 
increasingly large place for the state and its administration? "We will opt for State Socialism", wrote Halévy; "and we will consider that we will have learned from socialism that governing the economic world is necessary". xxxviii A final question, however, demanded further study: to evaluate "[...] in what - increasing - measure the public economy must merge with the State economy". xxxix

\section{THE GERMAN REACTION}

From the 1840's on, even though "the dream of German unity is becoming clear", ${ }^{\mathrm{xl}}$ proponents of a national economy, such as Friedrich List, and adherents to the Historical School, such as Wilhelm Roscher, Bruno Hildebrand, Karl Knies, and later Gustav Schmoller, directed their first offensive against the teachings of the English Classical economists. According to Halévy, it was an offensive that, in spite of a few interesting episodes, failed, for the most part, for two reasons: on the one hand, the German reaction remained too close to the lines of thought of its adversaries; on the other hand, it was never able to conceive a true alternative to the Classical economics, whether in terms of conception of a method, of a theory, or even of a doctrine.

By opposing his theory of the powers of production to the theory of exchangeable values adopted by Smith, Ricardo or Malthus, List emphasized the difference between public- and private-sector economies, and between a national and a cosmopolitan economy ${ }^{\mathrm{xli}}$. List's economic nationalism necessitated the adoption of the Historical method, a method that led him to several fruitful discoveries. It revealed the existence of successive stages of civilization, which would prompt the politician to work toward 
structured development. It also demonstrated that industrial education, especially taking the form of pragmatic protectionism adapted to concrete situations, is the best tool for economic government. Finally, it showed that the English success was the result of a veritable strategy: the combination of a flexible type of hidden protectionism and a clever free-exchange propaganda, both consistently implemented. After this was appreciated, it appeared to List that henceforth the goal of political economy would consist in "defining the conditions of existence for an economically normal nation", xlii specifying conditions propitious to the optimal realization, in space and in time, of the integration of all powers of production and any political, but above all, any geographic conditions. In short, "the ideal is an autonomous nation, supplemented by a colonial domain, developing within itself the strongest possible integration of the powers of production; the means for realizing the ideal is protectionism; the method for laying out the ideal and delimiting protection is the Historical method; such is List's doctrine." $x$ liii . The first doctrine to clear an undisturbed terrain, List's suffered from certain gaps and shortcuts. According to Halévy, however, it was nonetheless innovative on two points: interventionism and historicism. Should we accept without reservation the thesis stating that List was the precursor of two movements that would be dominant at the end of the nineteenth century in Germany: State socialism and welfare socialism? For Halévy, this was very debatable, because both List's economic psychology and his reflections on the ends of political economy are much like those of Smith and Ricardo. The improvement of conditions of distribution are not a part of List's agenda, since only growth in production preoccupies him; progress in culture, civilization, and morality only have meaning in his system when they are subordinate to growth in power. In fact, Halévy summarized, "List wants the 
politician to work to make a reality" of the great "Commercial Republic", the "legal fiction" imagined by Smith. ${ }^{\text {xliv }}$

Taking turn-of-the-century German philosophy as their source, and mainly Hegel, proponents of historicism denounced the confusion of 'abstract' and 'concrete' and of 'law' and 'norm' in the rationalism of the political economy of Ricardo. According to Halévy, competing methods of research on the true laws of evolution would take three successive forms characterized by different periods of historicist research: with Roscher, ${ }^{\text {xlv }}$ research on general laws for the development of nations, with Hildebrand and Knies, a proposal of general laws for the development of humanity as a whole, ${ }^{\mathrm{xlvi}}$ and finally, with Schmoller and the younger Historical School clearly pushing these first ambitious plans aside, studies, based on monographs and collective investigations, of the evolution of certain groups of historical phenomena considered in isolation. ${ }^{\text {xlvi }}$ Examining Carl Menger's ${ }^{x l v i i}$ response to Schmoller's arguments, Halévy felt that historicism had great merit, since it specifically delimited "the field of the deductive method" in economics and filled many lacunae of economic data. ${ }^{x i x}$ Even though historicism might have been able to satisfy a need for amassing information, Halévy concluded, however, that its contribution to the field and to the "organization of economic knowledge" was very weak. ${ }^{1}$ On the one hand, it proposed neither an alternate nor a perfected version of the Ricardian value theory; on the other hand, it pointed to real weakness where there should have been strength, that is, concerning its interpretation of evolution. Halévy ended his lecture on the Historical School by noting that: "[...] simply to declare that diverse elements of social, economic, legal, political, moral, and religious life exert reciprocal action on one another is, in short, to refuse to analyse, to refuse to 
explain what is transpiring. It is not certain whether among these diverse factors, there is one that is predominant and which exerts a causal action on the others. Let's invoke the living organism in which functions exert reciprocal action upon one another. Just because society presents a certain number of analogies with a living organism is not, however, a reason why the social sciences would necessarily have the same weakness as biology."li Announcing the sequel in his course, he continued: "Marxist socialism is a philosophy of history that seduced many minds, most likely because it took into account facts, at least contemporary ones. From its absolute triumph, or its relative influence, historical materialism contributed more, perhaps, to the organization of our historical knowledge than did the scholarship of the Historical School".

\section{MARXISM}

In November 1901, Halévy wrote to Bouglé: "Neither Schmoller, Wagner, any of the professors nor any of the eclectic thinkers interests me. I belong completely to Karl Marx (...). Marxism will be the linchpin for my course this winter"lii. Marxism, which fuses the diverse aspects of socialism, represented more specifically the interventionist component of the German reaction to the theses of the Classical economists. It demands governance of the economic sphere. Halévy judged it necessary to distinguish within Marxism that which emanated from Ricardian influence, his value theory, from that which emanated from Hegelian influence, the materialist conception of history. The interpretation that he proposed is the following: 
Marx adopts Ricardian value theory and uses it, through a combination of dialectical and logical procedures, to reveal contradictions, especially the contradiction, originally between use-value and exchange-value, between quality and quantity. ${ }^{\text {liii }}$ To his mind, the theory of labour-value was thenceforth in no case the transposition of the juridic formula 'from each according to his labour': "It would be better to say that a world in which value is measured based on the quantity of work completed is not an everlasting world, that it is a transitory form of human society, transitory since it is unstable, unstable because it is contradictory (the opposition of use-value and exchangevalue vitiates the whole theory of labour-value)." ${ }^{\text {liv }}$ This is in fact where Marx distinguishes himself from his orthodox followers as well as from Ricardo's socialist followers: all of them aim to restore an ideal situation of exchange in which the formula 'to every man according to his labour' would become a reality, whereas Marx emphasizes in the opposite direction the contradictory nature of exchange. Thus, he does adopt Ricardian value-theory, but only in order to demonstrate its contradictory character. While it is true today, the theory has been called to modify itself for the future, as is signalled, for instance, by the appearance of a value-theory linked to the cost of production to address possible questions about the difference in the organic composition of capital between branches. But, Halévy asks, what if Marx's theory were simply wrong? This is what the Marginalists advocated at the very end of the 19th century with a new value theory and a new distribution theory to solve logically the Ricardian paradoxes. Development in the works of Marginalists, such as S. Jevons, L. Walras, and C. Menger, ${ }^{\text {v }}$ led Halévy to specify "the law of progress for abstract political economy"; did Marginalism refute Socialism? "One thing is true. From a doctrinal point of view, 
conservative political economy and socialist political economy have each in turn been one step ahead of the other. In 1817, the followers of Adam Smith and Ricardo have the upper hand: they have a doctrine that the "socialists" do not have. From 1817 to 1867 , from the New Principles of Sismondi until Marx's Das Kapital, the socialists take back the upper hand and ceaselessly enrich their critique of orthodox political economy with new arguments. In 1870, conservative political economy takes back the upper hand, and Marxist value-theory becomes obsolete."lvi

The Marginalists' success must, however, be put in perspective: on the one hand, the Fabians in England put into action a new value theory in order to bring socialism back to its roots; ${ }^{\text {lvii }}$ on the other hand, the Marginalists themselves underline the distinction between a theoretical and a practical political economy. Does the erroneous character of the Marxist theory of labour-value nullify the integrity of Marx's message; does it render the study of the other central thesis of his work, industrial mergers, fruitless? For Halévy, in order to give a verdict, it is necessary to study the true foundation of Marxism: his materialist conception of history.

In order to understand Marx's historical materialism, it is essential to specify what he borrows from Hegel's philosophy and how he distinguishes himself from it. ${ }^{\text {liii }}$ From Hegel's philosophy, Marx kept the evolutionist orientation and the idea that "the reason for progress is the perpetually contradictory nature of things". But, since Marx was influenced by the theses of Bruno Bauer and Ludwig Feuerbach, and since he placed himself in the general context of "the German philosophy of liberty", Marx distinguished himself from Hegel by placing man, not God, at the heart of his theory. Halévy contrasts 
the two dialectical approaches in the following terms: "In the works of Hegel, divine thought condemns and at the same time justifies, as a form subalternate to itself, every form of being, of life, and of society: it results in a speculative optimism, in a philosophy of practical indifference. Marx takes man's point of view; dialectic is useful to him above all because it demonstrates the absurd, unstable, transitory character of the present and gives a reason for the future versus the present, for the present versus the past. Hegel's dialectic is justificatory and conservative; Marx's, critical and revolutionary."lix

What necessity makes of man the driving force of history? Practical, not logical necessity; it is action, economic action which becomes a driving force when it clashes with real, concrete contradictions: "these contradictions", Halévy stresses, "have a concrete, real, economic character; they are conflicts of interests, whether of individuals or of classes, in other words, they are historical struggles between individuals or groups of individuals." Marx draws from this interpretation of history the lesson of a growing capitalist concentration, which can only lead to a terminal crisis and the establishment of a radically different economic and social regime.

What should we retain, according to Halévy, of this interpretation of history? He initially refuses, in his 1902 course, to discuss the philosophical landscape, particularly the question of the "relationships between thinking and acting". li $\mathrm{He}$ nonetheless considers this Marxian interpretation productive over all, especially in relation to the sterility of historicism: "It is a fact," he writes, "that in the nineteenth century, economic causes exerted a considerable effect on the unfolding of history; and that, as a result, for that particular era, historical materialism bears a mark of relative truth." 
in the course, he proposes that two things be retained from Marxism: the independence of the thesis of industrial concentration with respect to the invalidated theory of labourvalue and capitalist surplus-value, and the importance of the reality of economic concentration. At this point, two questions are raised for discussion: To what extent, if the thesis of concentration growth is verified, does it lead to the downfall of capitalism and the advent of integral collectivism? To what extent is there indeed a general movement toward growing concentration?

\section{THE PROBLEM OF CONCENTRATION}

In his 1902 course, Halévy showed that the failing of the Marxist theory of concentration is to be found in its radicalism, in its monolithism. In reality, a movement toward concentration is clearly apparent, but counter-tendencies exist, and what is revealed by contemporary capitalism is a process of evolution, rather than a radical change in economic logic.

The Marxist theory of concentration owes much to the insights of S. Sismondi and

C. Pecqueur. ${ }^{\text {xiii }}$ Marx does not adopt the thesis of the former, which sees exchange at the origin of the movement toward concentration, and prefers to emphasize the importance of the first surplus-value in the primitive accumulation process. Three phases, sanctioning three successive moments of bourgeois exploitation, have punctuated the evolution: simple cooperation, division of labour, and mass production. Accelerated concentration, characterised by this logic of the exploitation of the worker by the capitalist, is followed by a last phase, one of centralisation, which sees the intensification of competition 
between capitalists. Halévy opportunely specifies, "Marx copies Sismondi word for word, but back to front. The prime motor of the whole movement is exploitation of the worker by the capitalist. Mass production, division of labour, machinery are nothing more than refined parts of this exploitation. The struggle undertaken by capitalists to destroy one another is simply the last phase of the fever of capitalist accumulation."

What is the eventual cost of such a process, according to Marx? He reveals himself here to be as pessimistic as Sismondi and as optimistic as Pecqueur inasmuch as he considers each phase of the exploitation to have a positive side and a negative side; "Cooperation", specifies Halévy for example, "leads to the despotism of capital in the workshop, but it also creates the assembly, the collectivity of the workers. Capital thus envisages the division of labour, which debases the worker, which reduces him to the level of a tool without intelligence. The division of labour has, however a positive side in that it establishes, in manufacturing, organisation in the production process, according to a rational and systematic plan, in contrast to the anarchy of production in society. The invention of machines creates a new anarchy, by progressively eliminating the worker in favour of the mechanical tool; but it has an advantage in that it despecialises the worker, giving him again the possibility of becoming a whole man", ${ }^{1 \times v}$. This contradiction which repeats itself ever more intensely from one crisis to the next until the final cataclysm. In the episode ending the evolution, however, as Halévy points out, "with one last action in the exchange dialectic, the negative side disappears completely in this destruction of capitalist society; the positive side remains: communism." 
Do the facts validate this interpretation? ${ }^{\text {xvii }}$ Halévy makes a distinction here between concentration in agriculture and concentration in industry.

With regard to agriculture, he proceeds from the debate between Edouard Bernstein and the orthodox Marxists. Bernstein, relying heavily upon statistics pertaining to real estate ownership, showed that in this area there is a fragmentation of property holdings and that even in cases of concentration, no real change in the mode of exploitation is to be found. To this, his adversaries replied that what Marx had evoked was more a phenomenon of intensification and that, furthermore, he had stated that the capitalist regime knowingly maintained a regular system of "laws for the expansion and the diminution" of major real estate properties, rendering perpetual a situation where "the very small landowner is an agricultural proletarian". lxviii Halévy, situating himself more in Bernstein's camp, presents three arguments to supporters of the Marxist interpretation: firstly, the fact that one cannot, without distortion, successfully identify the urban proletarian completely with the small agricultural proletarian. He writes: "[...] in urban industry, the exchange system has completely, or very nearly, eradicated all traces of the previous system in which man produced for his own personal use and only exchanged the part of his produce which exceeded his needs; in agriculture, the capitalist regime permanently maintains, with successive crises of excess and want, a class of men which produces according to use-value before producing according to exchange-value."

Secondly, he considers that, even if one were to accept the hypothesis that the maintenance of an average-size real estate property is compatible with Marx's thesis, it still remains that movement toward concentration here does not signify a polarisation 
comparable to the case of industry. Thirdly, he notes as significant the indecision, the vagueness, and the ideas, often far removed from Marxism, of the major European socialist parties with respect to their agrarian policy proposals.

Industry, for its part, validates more effectively the thesis of concentration. Here too, however, Halévy has several reservations regarding the interpretation offered by orthodox Marxism. To start, one must note the endurance, even the vitality, of small industries that develop in the shadow of larger industries. Next, it is important to recognise that increase in production is accompanied in many cases by a general increase in consumption, and not by an increase in poverty. How might one explain this fact? In certain cases, underlines Halévy, "the centralisation of capital may take place not only by means of destruction, but even more so by the association of small capitalists: each business is, in this second case [...] no longer an absolute and despotic monarchy, but a republic, or a constitutional monarchy, in which the citizens are a large number of small shareholders." $\mathrm{xx}$ Finally, economic evolution has seen the progress of trade unions, both in number and in organisation. ${ }^{\text {kxi }}$

Even within the limits of its influence, the concentration of capital is deflected by compensatory acts, which result in the general improvement of working conditions. It was thus not surprising to Halevy that contemporary socialists had undergone a conversion: "It is no longer a question of predicting the dialectic cataclysm, which will, sooner or later, destroy capitalist society, and of limiting one's efforts to preparing the working class, grouped into revolutionary bodies, for the decisive and inevitable day when the economic contradictions created by the capitalist world will have become 
untenable. It is for them now a question of envisaging the appropriate measures to cancel or reduce profit within a still capitalist society."

\section{UNION, COOPERATIVE AND STATE}

But what are the measures, which, from now on, will allow us to combat the growing disproportion of riches and to give value to a new socialism? Halévy defines them precisely, announcing here the grouping of the last three lectures in his 1902 course: "Here we have the workers' union $[\ldots]$, the cooperative, the public service, which significantly modify the distribution of social revenue. May one not, by taking things to their limit, suppose that, if these different institutions develop progressively and tend consistently to eat away at the institutions that are truly capitalist until they are completely eliminated, we would end up with a collectivism derived from the current capitalism, not by means of revolution, but by means of imperceptible evolution. An evolutionary neo-socialism is tending toward taking the place of revolutionary Marxism."lxxiii

Marx observed the rapid expansion of trade unions in England and, faced with this phenomenon, his attitude was ambivalent; on the one hand he praised these first efforts of the working class to organise itself and noted their effect on the development of factory legislation; on the other hand, observed Halévy, he "has too much faith in capitalism to believe that it is desirable or possible to disrupt the course of capitalism by means of union or legislative intervention", and from that moment on, he believed that new 
legislation, whether decreasing or intensifying the workload, would only accelerate the movement toward concentration. Nevertheless, a few years later, the socialists were obliged to acknowledge the increasing momentum of trade unions -- in Germany, which saw, particularly after the law of exception of 1878 , the imposition of a positive policy of reform implemented by an imperial government concerned with defusing revolutionary socialism. It was essentially England, however, which continued then to propel the movement - "It is England, noted Halévy, which provided Europe with the classical type of union worker, which taught Europe about the forms of liberalism, or of parliamentarianism in the factory, just as it taught Europe about the forms of liberalism and parliamentarianism in politics"llxxiv - and the last third of the nineteenth century saw the development of trade-union socialism, of which Sidney and Beatrice Webb were the principle advocates. ${ }^{\mathrm{lxv}}$ This was a pragmatic socialism and Halévy emphasised its uniqueness in the interpretation provided by the Webbs: "instead of insisting, like Marx, upon the radical opposition of interests between the workers and the all powerful employer, upon the despotism of the capital in the factory, they place emphasis instead upon the economic institutions which are presently tending to limit the omnipotence of capital in the factory, upon the democratic features of mass production." methods are thus mobilised by the trade-union movement: mutual insurance, collective bargaining, and above all, legislative decisions. They allow it to achieve a certain number of aims, in particular the fixing of rules and minima regarding working conditions and wages. Trade unionism thus reaches its objectives, but, as Halévy points out, within very precise limits, for it is not a question for the union, "of eliminating profit, 
but on the contrary, of taking as a given the relationship between the capitalist and the salaried employee, in order to improve the condition of the wage-earner".

It is the cooperatives that see their goal as the elimination of profit. The movement was first utopic with Robert Owen, then doctrinal with Ferdinand Lassalle, who supported exclusively the production cooperative. By 1890 , guided by the contributions of Charles Gide, Sydney and Beatrice Webb, and Franz Oppenheimer, ${ }^{\text {lxxvii }}$ it opted for consumption cooperatives, which permitted the suppression of the classic conflicts between consumer and producer and between capital and labour. Making use of the cooperative/union complementarity, modern socialism thus predicted the "progressive and spontaneous realisation of the collectivist regime". lxxviii The success, however, of the cooperative movement must be qualified. Objections for reasons of principle may be made: Cooperativism offers no precise rules concerning the setting and graduating of salary levels, it does not lead to a radical limitation of profit, and it offers no real solution to the problem of real-estate income. Above all, however, one might have reservations about the potential expansion of such a system, which is aimed neither at the very rich nor at those who are excluded or very poor, which is integrated neither in the country, nor truly in the big urban centres, and finally, which remains reasonably weak in terms of its contribution to the development of global wealth.

Halévy concluded his lecture on cooperatives by remarking: "[ $\ldots]$ the development of the functions of the State constitutes nowadays a much more important historical phenomenon than the development of cooperatives: State control has thus a greater historical importance than Cooperativism."lxxix Unfortunately, Halévy did not write out the last lecture of the 1902 course, devoted to State control. ${ }^{\text {lxx }}$ The content of 
this lecture may nevertheless be deduced in a couple of ways: by reproducing Halévy's

outline for it, ${ }^{\text {lxxi }}$ or by examining his writings on the State shortly afterwards, between 1902 and 1904.

Halévy proposed for the last lecture of 1902 the following outline:

"Introduction: the socialists and the State. I. Defiance of the fiscal State (military, police). II. The Ricardianism of Marx: his prejudices regarding the idea of the State. III. The German social democrats since 1880. State socialism.

Origins of State socialism. Welfare socialists (Brentano, Schmoller). State socialists: Wagner. Professor and reformer.

A. Tendency towards dogmatism.

a. Partial reinstatement of classical psychology. The economic motive. The eternal and the historical.

b. Incorporation of historical materialism into classical teaching. The theory of the effect of law upon the economy. Social rights.

B. The role of the State.

a. The three principles of organisation. Critique of the privacy principle. The gemein(s) ...

b. The law of increasing expansion of State activity.

\section{Conclusion}

Historical importance of this doctrine; a) mention the increase of State functions; b) The point toward

which doctrines converge; nationalism, historicism, socialism. 
Appreciation of complex doctrine: a) advantages and disadvantages of mass production; b) production

and distribution; c) the increase of the functions of the State which do not conflict with the

development of individual businesses; d) multiplication of the forms that State intervention may

take.

But the fact remains; manifests itself in the history of institutions, - is reflected in the history of doctrines".

He thus notes as fact the rise of a principle of State control linked to economic activity. At the same time, he proposes, for example, during the controversy between himself and Vilfredo Pareto, that the State is "essentially, the instrument of defence of all individuals against all groups" (Halévy 1904: 1113). He writes more extensively still to Bouglé, in November 1902: "I believe that the State is not essentially tyrannical: it is essentially the instrument of defence of society in general against particular societies, of all individuals against all groups. It no longer corresponds to its essential character when it becomes an instrument defending groups and particular societies. But, when it fulfils its function, when it works to struggle against the predominance of particular societies and groups, to be alarmed by its action, because that action tends to reinforce itself and makes itself, later, a terrible weapon in the hands of these groups, is to get caught up in a vicious circle and to give up the only means in our power to defend freedom. " «xxxii 
The State has, then, essentially, a political function to preserve freedom through the control of power and the regulation of phenomena of domination. Halévy, here again, states clearly: "It should not be said that men are born free and establish the State to increase their security at the expense of their freedom. It should be said instead that men wish to be free and that, insofar as they wish to be free, they establish the State to increase at once their security and their freedom"laxxii . Freedom is not defined by the absence of constraint, a concept which Halévy describes as "anarchic, antisocial" - but by the autonomous "exercise of reason and faith in reason". Yet how does this function evolve within the framework of a society where economic practices dominate? Are social and economic practices more effective than others in enabling the State to realise its "essence", to use Halévy's term? He offers here an ambivalent answer, but one which is, for its time, predominantly optimistic: on the one hand, it seems to retain the lesson of historical materialism and acknowledge that economic practices, having the particularity of being able continually to reconcile conflict and cooperation, are promising and may be able to teach the arduous lesson of pluralism and common government. On the other hand, he does not deny that the same practices, if unchecked, are potentially conducive to new tyrannies. In his entry on "socialism" in the Vocabulaire critique et technique de la philosophie, Halévy points out that there exist already two distinct forms of "State socialism": a "democratic form", represented by Chartism, the socialism of Louis Blanc in 1848 and by "current Marxism", which aims for an integral democratisation of the State and for the emancipation of the individual, and an "aristocratic form" which he associates with the names Hegel, Carlyle, Rodbertus, and Wagner, and which was the form applied to the social politics of Bismark. He clarified it there: "Socialism, thus 
conceived, has broken all ties with the Anglo-French individualism of the eighteenth century. The individual exists only to achieve certain ideal and impersonal aims - art, science, religion - which are embodied by the State. But, precisely because the individual removed from the State is an abstraction, with his incorporation in the State, the individual finds his true rights realised. This "State socialism" constitutes a sort of bureaucratic paternalism where the individual, through the alienation of his own rights, finds his material and moral happiness guaranteed".

\section{CONCLUSION}

Halévy's first lectures on European socialism bear the undeniable trace of his historical and cultural milieu; they reflect a number of the questions, debates, and significant controversies of the "Golden Age" of the Third Republic in France. It is important nonetheless to emphasis the fact all these elements were appropriated by the young philosopher-historian to propose his own personal framework for contemplating and interpreting the course of the economic and social events of his time.

Two aspects were significant. Firstly, his positive interpretation of Marx work; secondly his analysis of the relations between économics and politics which shapes his general intellectual framework.

Various commentators have clearly qualified the classic observation made by Louis Althusser ${ }^{\text {lxxiv }}$ related to the theoretical weakness of the reception of Marxism in France at the turn of the nineteenth and twentieth centuries ${ }^{\mathrm{kxxv}}$. To this end, these 
commentators relied on the uncovering of a demanding non-Marxist reception of Marx by the French intellectuals Lucien Herr, Charles Andler, or Georges Sorel, among others. Elie Halévy clearly participates in this unexpected reception. His interpretation, however, of the potentialities of Marxism differs significantly from the classic one in France at this time proposed, for example, by Charles Andler. Andler was sensitive to the pluralism of socialist traditions and thus careful to examine the process of the decomposition of Marxist dogma, condemned for its economic deficiencies or for its disdain for law and [morale]. In contrast, even if he in no way hides Marx's approximations, Halévy considers that the fruitfulness of Marxism resides in its materialist interpretation, and above all in its invitation to reflect on the political role of economic conflicts. This is a point which the French philosopher and closest friend of Halévy, Alain best sums up when, commenting ten years later upon Halévy's first volume on the history of the English people in the nineteenth century (published in 1912), he writes to his friend, "Industrial barbarism is the effect of a previous barbarism, and mechanisation has nothing to do with it - on the contrary. Mechanisation has, rather, made the old set of habits unbearable, by giving them a clear conscience, by reporting them in the media, by making them progress from the en-soi to the pour-soi. This picture is worthy of Marx; and there you have your model"lxxxvi

Halévy personal framework might be now summed up in the following few words. Halévy's attention was absorbed by the rise of modern industrial societies, within the European sphere, in the $19^{\text {th }}$ century. For this reason, very early on, he chose to turn his interest to the political impact of economic development. He observed that with the disappearance of military and militaristic societies, some new interactions arose, resulting 
from cooperation and conflict, and in constant evolution, became generalized among producers, authorizing new forms of control and regulation by the collective. In this context dominated by industry, even if he noted the rise of cooperatives and trade-unions, Halévy underlined the inexorable growth of the State and the important and positive political role which it would play from that point on, without disguising the fact that, without restraint, the growth of the State could also become dangerous: "I end with the State", he wrote to Bouglé in may 1902, "it is not my fault and the liberals and libertarians cannot hold me responsible for it"'lxxxvii.

Halévy's originality can be even more precisely stated: both a philosopherhistorian and an economist, he represents, in France, one of the rare intellectuals of his generation to have tried to cross political reflections on the foundations of the new French Republic with reflections on the economic mechanisms of the new industrial societies. 
Résumé

Les travaux tardifs d'Elie Halévy (1870-1937) ont permis de le classer parmi les grands auteurs libéraux, en particulier sur le plan économique, au $20^{e}$ siècle. Il existe néanmoins un tout autre Halévy, plus républicain que libéral, que l'on peut retrouver dans ses contributions antérieures à la Grande Guerre. Elles témoignent de la présence d'un auteur plus réformiste, plus attentif aux conditions concrètes de la liberté des individus et des peuples, et, dès lors, plus nuancé sur le projet d'un contrôle politique et social de l'économie. Ce "premier" Halévy mérite examen. D'abord parce que cet aspect de son auvre est assez peu connu. Ensuite, en raison de son intérêt intrinsèque, à la fois par la qualité des enquêtes historiques qu'il mène alors, mais aussi par la valeur des réflexions qu'il conduit sur les relations entre économie, éthique et politique. L'étude de la première série de leçons, inédites, sur l'histoire du socialisme européen, qu'il donna en 1902 à L'Ecole Libre des Sciences Politiques, permet de vérifier la présence de ce " premier " Halévy.

Abstract

Elie Halévy's later works have made him one the most renowned French liberal thinkers of the 20th century. I want to argue, however, that there exists another facet of the man,more republican than liberal, to be found in his pre-Great War papers. 
Halévy reveals himself as a man with reformist tendencies, concerned with the concrete aspects of freedom, both for individuals and peoples, and therefore holding more qualified views on the project of a political and social control of the economy. This unknown Halévy deserves our attention, not only because this aspect of his work is hardly ever mentioned, but also because first it is an important contribution to the history of economics, and, second, it is an interesting and valuable contribution to the study of the relation between ethics, politics and economics. My analysis focuses on Halévy's unpublished first series of lectures on the history of European Socialism, delivered in 1902 at the Ecole Libre des Sciences Politiques,in which the major features of this early Halévy can be best identified.

\footnotetext{
${ }^{i}$ See Raymond Aron, "Pour le centenaire d'Elie Halévy", Bulletin de la société française de philosophie, 46 (1971); Nicolas Baverez, Raymond Aron. Un moraliste au temps des idéologies (Paris : Gallimard, 1993).

ii Elie Halévy, "L'ère des tyrannies", in L'ère des tyrannies: Etudes sur le socialisme et la guerre (Paris, Gallimard, 1938).

iii See, Hugh Stuart Jones, "The Era of Tyrannies: Elie Halévy and Friedrich von Hayek on Socialism," European Journal of Political Theory, 1 (2002), 53-69..

iv Elie Halévy, «Les principes de la distribution des richesses », Revue de métaphysique et de morale, 14 (1906) : 545-595.

${ }^{\vee}$ See Ludovic Frobert, Elie Halévy: République et économie 1896-1914, (Lille: Presses du Septentrion, 2003).

${ }^{v}$ Concerning French republicanism see Claude Nicolet, L 'Idée républicaine en France (Paris: Gallimard 1982), Nicolas Tenzer, La République (Paris: Presses Universitaire de France 1993) and Alain Renaut et
} 
Sylvie Mesure, "La discussion républicaine du libéralisme moderne" in Histoire de la philosophie politique, dir. A. Renaut (Paris : Calmann-Lévy 1999).

vii Reference to the Platonism of the early Halévy. Elie Halévy, La théorie platonicienne des sciences, Paris: Alcan, 1896).

viii English translation, The Growth of Philosophical Radicalism, first edition, London 1928.

ix On the "Halévy thesis" and the debates that it sparked, see the recent synthesis in Michael R. Watts, The Dissenters ( Oxford: Clarendon Press 1995) 2: 373-375.

${ }^{x}$ Elie Halévy, Histoire du peuple anglais au 19e siècle, vol. 1, L'Angleterre en 1815 (Paris : Hachette 1912).

${ }^{\mathrm{xi}}$ English translation, The Era of Tyrannies: Studies on socialism and war, New York, 1965.

${ }^{x i i}$ Not yet translated into English.

xiii Raymond Aron, foreword Elie Halévy, Histoire du socialisme européen (Paris: Gallimard 1948).

xiv Elie Halévy (1948): 295-297.

${ }^{\mathrm{xv}}$ Jean-Paul Sartre, Entretiens sur le politique (Paris : Gallimard 1949) : 102.

${ }^{\mathrm{xvi}}$ Alain, Correspondance avec Florence et Elie Halévy (Paris : Gallimard 1958) : 314.

xvi Elie Halévy (1996) : 481.

xviii On Halévy's in part unjustified pessimism vis-à-vis English socialism, see François Bédarida, «Elie Halévy et le socialisme anglais », Revue historique, 254 (1976) : 371-398; vis-à-vis liberal democracies, see Raymond Aron, «L'ère des tyrannies d'Elie Halévy », Revue de métaphysique et de morale, 46 (1939). xix Elie Halévy, La théorie platonicienne des sciences (Paris: Alcan 1896).

${ }^{x x}$ See as significant his undertaking at the time of the Dreyfus affaire (Halévy 1996: 203-40). On his involvement, see Vincent Duclert, "Elie et Daniel Halévy dans l'Affaire Dreyfus", in La famille Halévy 1760-1960, ed. Henriette Guy-Loé (Paris: Fayard 1996).

xxi John A. Hobson, The Social Problem, (London: Nisbet, 1901).

${ }^{x x i i}$ Revue de métaphysique et de morale, 1901, vol. 9, July supplement, p. 4. The reviews were all anonymous. The author can, however, still be identified in numerous cases as Halévy, since there is very strong probability that he took personal responsibility for reviewing the publication of the work of an English economist.

xxiii Elie Halévy, La formation du radicalisme philosophique (3 vol. Paris: Alcan 1901-1904).

xxiv Elie Halévy, Thomas Hodgskin 1787-1869 (Paris: Société nouvelle de librairie et d'édition 1903).

xxv Elie Halévy, « La doctrine économique de Saint-Simon », La Revue de Mois, 4: 641-676, et 6: 39-75 (1908).

xxi In the course of the May 18th and June 8th class meetings of 1905, Halévy presented this definition, Bulletin de la Société française de philosophie, 1905, 197-198.

xxvi Elie Halévy, "La naissance du méthodisme en Angleterre", Revue de Paris, 13, 519-539 and 841-867.

xxviii Thierry Paquot, Les faiseurs de nuages: essai sur la genèse des marxismes en France 1880-1914 (Paris : Le Sycomore 1980). 
xxix Madeleine Rebérioux, "Le socialisme en France de 1871 à 1914", in Histoire générale du socialisme, vol. 2, dir. J. Droz (Paris : Presses universitaire de France 1997).

${ }^{x x x}$ Sébastien Laurent, L'Ecole libre des sciences politiques de 1871 à 1914. Mémoire de l'Institut d'études politiques de Paris, 1991.

xxxi Emile Cheysson, for example.

xxxii On Célestin Bouglé and François Simiand's influence, see letter, June 1901, family archives, Sucy-enBrie. Philosophers, alumni of the Ecole Normale Supérieure, and members of the team of the periodical L'Année Sociologique both, Bouglé and Simiand had an excellent knowledge of German economic literature. Bouglé had put his name to a small monograph entitled Les Sciences Sociales en Allemagne; Simiand regularly reviewed new German releases on economics for the "economic sociology" section of L'Année Sociologique. On Lucien Herr's influence, see (Halévy 1996: 697).

xxxiii A reading of different lectures, and in particular transitional passages, seems to corroborate this order. In June 1901, working on the first outlines of his course, Halévy furthermore announced a plan very close to this one (see Letter to C. Bouglé, family archives).

${ }^{\text {xxxiv }}$ Halévy Collection, folder 2.1, "evolution of economic and social doctrines in England and Germany in the second half of the 19th century", 12 pages, page 6.

${ }^{\text {xxxv }}$ Ibid., page 9.

xxxi Ibid, page 10 .

xxxvii Ibid., page 10.

xxxviii Ibid., page 10 .

xxxix Ibid., page 11.

${ }^{\mathrm{xl}}$ Folder 7.4, "Friedrich List and the National Political Economy", 22 pages, page 1.

${ }^{x l i}$ Friedrich List, Das National System der Politischen Okonomie [The National System of the Political Economy] (1841). Halévy used the French edition: Système national d'économie politique, (Paris : Capelle 1851). Halèvy also relied on W. Lewis, "History of Protectionism", Revue d'économie politique, 10 (1), 1896.

xlii Ibid., pages 11 and 12 .

xliii Ibid., page 16.

xliv Ibid., page 22.

${ }^{x l v}$ Halévy seems to have principally used: Roscher, Grundriss zu Vorlesungen über die Staatswirthschaft. Nach geschichtlicher Methode (1843), Ansichten der Volkswirthschaft (1861), but he also used System der Volkswirthschaft, above all vol. 1, Die Grundlagen der National Okonomie, (1854). He also relied on Adolph Wagner's commentaires, Grundlegung der Politischen Oekonomie (1876).

xlvi The two main sources for Halévy were the following: Bruno Hildebrand, Die Nationalökonomie der Gegenwart und Zukunft (1848); Hildebrand, "Die gegenwärtige Aufgabe der Wissenschaft der Nationalökonomie", in Jahrbücher für Nationalökonomie und Statistik (1863); Karl Knies, Die politische Oekonomie von Standpunkte der geschichtlichen Methode (larger edition of 1883). 
xlvii Main source: Gustav Schmoller, Grundriss der Allgemeinen Volkswirtschaftslehre, of which the first volume was available in 1901.

xliii Here Halévy mentions: Carl Menger, Untersuchungen über die Methode der Sozialwissenschaftern und der Politischen Ökonomie insbesondere, 1883.

xlix Folder 7.4, "Historicism", 20 pages, page 17.

${ }^{1}$ Ibid., page 19.

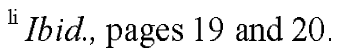

${ }^{\text {lii }}$ Elie Halévy (1996): 313.

liii Halévy's bibliography gives the following references for study of Marx's value-theory: Karl Marx, Das Kapital (Librairie du progrès French translation of volume I (1875) and another translation by Giard and Brière, volume I (1900), II (1900), and III (1901 and 1902); for the 1902 course, he used the German edition for the contents of volume III); K. Marx, Misère de la philosophie, new edition by Girard and Brière (1896); K. Marx, Salaire, prix, profits (1899).

liv Folder 6.2, "Marxism. Value-theory", 22 pages, page 19.

${ }^{\text {lv }}$ In the 1902 course, it seems that Halévy was above all interested in the Austrian version of marginalism. He used Menger, Grundsätze der Volkswirtschaftslehre (1871) and Eugen Böhm-Bawerk, vol. 2 of Kapital und Kapitalzins, entitled Positive Theorie des Kapital (1889). In his bibliography, however, he also mentions Stanley Jevons, Theory of Political Economy (1871) and Léon Walras, Eléments d'économie politique pure (third edition, 1896). He also cites Eugène Petit, Etude critique des différentes théories de la valeur (1897).

${ }^{\text {lvi }}$ Folder 11.2, "The Austrian theory of value and interest", 8 pages.

lvii Two sources here: Fabian Essays (1899), Halévy mentions in particular Bernard Shaw's contribution, "The Basis of Socialism Economic"; and Edouard Bernstein, Zur Geschichte und Theorie des Socialismus (1901).

lvii Concerning the materialist interpretation of history, Halévy lamented not being able to refer to L'Idéologie allemande. He did, however, cite the following sources: Marx, Contribution à la critique de la philosophie du droit de Hegel (1843), (French translation by Giard and Brière, 1895); Marx, Manifeste Communiste (in the translation proposed by Charles Andler, 1901); Friedrich Engels, Herrn Eugen Dührings Umwälzung der Wissenschaft (1878).

lix Folder 7.1, "Historical materialism", 15 pages, pages 8 and 9.

${ }^{\mathrm{kx}}$ Ibid., p. 10.

lxi Ibid., p. 14. Regarding this, one should note the controversy following George Sorel's exposé "Le matérialisme historique", Bulletin de la société française de philosophie, 2, 1902.

kxii Ibid., p. 14.

${ }^{\text {lxii }}$ Simonde Sismondi, Nouveau principes d'économie politique (1820); Constantin Pecqueur, Des interest du commerce de l'industrie, de l'agriculture et de la civilisation en general sous l'influence des applications de la vapeur (1839). 
lxiv Folder 11.3, "The Marxist theory of capital concentration", 15 pages, pages 13 and 14.

${ }^{1 x v} I$ Ibid., page 14.

lxi Ibid., p.15.

${ }^{1 x w i}$ Regarding the recent debates around this question, Halévy quotes: Karl Kautsky, Die Agrarfrage (1899); Edouard Bernstein, Die Voraussetzungen des Sozialismus und die Aufgaben der Sozialdemokratie (1899); Emile Vandervelde, Le collectivisme et l'évolution industrielle (1900).

kxuii Folder 11.1, "Capital concentration in agriculture", 12 pages, page 8.

kxix Ibid., page 8 .

${ }^{\mathrm{kxx}}$ Folder 7.2, "Capital concentration in industry", page 15.

lxxi "The concentration of capital is accompanied, in the modern world, by an inverse movement toward concentration of the working force", ibid., page 17.

lxxii Ibid., page 20.

lxxiii Folder 1.3, "Trade unionism", 15 pages, page 1.

lxxiv Ibid., page 2.

${ }^{\text {lxxv }}$ Halévy mentions Sydney and Beatrice Webb's Industrial Democracy (1897).

lxxi

lxxvii Charles Gide, La coopération (1900); Beatrice Potter (Mrs. Webb), The cooperative movement in Great Britain (1899); Franz Oppenheimer, Die Siedlungsgenossenschaft Versuch einer Positiven Ueberwindung des Kommunismus durch Lösung des Genossenschaftsproblems und der Agrarfrage (1896); Charles Andler, "Le role social des cooperatives", Revue de métaphysique et de morale, 8, 1900, pp. 121134.

lxxviii Folder 9.4, "Cooperatism", 17 pages, page 14.

lxxix Ibid., page 17.

${ }^{1 \times x x}$ Letter to Bouglé.

${ }^{\text {kxxi }}$ Folder 6.2, "State socialism". He notes the following bibliography: A. Wagner, Grundlegung des Politischen Oekonomie (1876); G. Sulzer, Die Zukunft des Sozialismus (1899); and Vandervelde's work mentioned above.

lxxxii Elie Halévy (1996): 329.

lxxxiii Elie Halévy (1901-1904), 3: 243.

lxxiv Louis Althusser, Pour Marx (Paris: Maspero 1973) : 14.

${ }^{1 x x x v}$ Daniel Lindenberg et Meyer, P.A, Lucien Herr, Le socialisme et son destin (Paris: Calmann-Lévy 1977); Christophe Prochasson, Les intellectuels et le socialisme (Paris: Plon 1997).

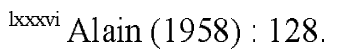

lxxxvii Elie Halévy (1996): 322. 